\title{
WHAT ARE PRECEDENTS AND HOW SHOULD JUDGES HANDLE THEM? CONSIDERATIONS BASED ON THE JURISPRUDENCE OF THE EUROPEAN COURT OF HUMAN RIGHTS
}

\begin{abstract}
The Practice Statement of the House of Lords of 1966 posed the principle for the use of precedent in English law. The European Court of Human Rights developed its own stance on the authority of precedent in various judgments. The positions of the two jurisdictions on the issue are substantially the same. The precedents are to be followed and their authority is binding for the courts.
\end{abstract}

Key words: Precedent, Distinguishing, Overruling, Binding Force, Administration of Justice.

\section{The Notion of Precedent}

\subsection{INTRODUCTION}

"Our legal system belongs to the continental law and we do not follow precedents." The author of this text has on many occasions been in the position to hear such a phrase, or a similar one, either in his home country Serbia, or elsewhere in Europe. Although the statement may seem logical at first glance the question is, what the phrase actually means?

Let us imagine that a "type N" case comes before a judge and the judge rules in favour of the plaintiff. What happens when the same "type N" case comes before the judge at the same court of law next time? Is the judge entitled to rule for the defendant? The answer is definitely in the negative, provided there is identity of the two cases.

The answer that has just been given is based on two main considerations. Deciding differently in a subsequent case of the same type is some-

\footnotetext{
* Attorney at Law, Professor of the Law School of Union University in Belgrade, Former Judge of the European Court of Human Rights in Strasbourg e-mail: dragoljub.popovic@gmx.net
} 
thing that contradicts our elementary sense of justice. This can be proven at any time by interrogating on the subject a layman who has no formation in law. Moreover it contradicts a philosophical precept of fairness, which demands that the equal should be treated equally and the unequal unequally.

At this stage the concept from the title of this paper appears to be unavoidable. Precedents are not to be regarded as a concept belonging exclusively to the Common Law treasury. They always play a role when the administration of justice takes place. Precedents are to be followed not because there is a certain provision in written law, which prescribes judges to follow them. They are to be followed because such a practice originates in the essential commands of justice.

\subsection{CONTENTS OF A JUDGMENT - RATIO DECIDENDI AND OBITER DICTA}

A judgment of any court of law always contains an element, which appears to be the most important. The Common Law has given the name of ratio decidendi to that particular element. It represents the grounds of the court's decision, and it is defined as the "propositions of law, which are necessary for the disposal of the case on the facts". ${ }^{1}$ The ratio decidendi is considered to be binding. It is to be noted that a judge giving a judgment in the system of Common Law usually does not state what the ratio decidendi is. That element is to be found among the reasoning in a judgment by a judge, coming next to the one who rendered the decision and using the previous judgment as authority. ${ }^{2}$ However, it is exactly that part of a judgment, which is to be followed. In other words, it is binding on "the decision-making of a subsequent court". ${ }^{3}$

Apart from the decisive element of a judgment there are still other important items in a court's reasoning. They are called obiter dicta. The obiter dicta are not binding, but they may have persuasive authority. ${ }^{4}$

\subsection{IDENTITY OF CASES AND THE PROBLEM OF DISTINGUISHING}

A sitting judge, although recognising the previous authorities will always face a problem, which consists in a preliminary question. The ques-

1 Whittaker, S., "Precedent in English Law: A view from the citadel", in: Hondius, E. (ed.), 2007, Precedent and the Law, Brussels, p. 41.

2 David, R. / Jauffret-Spinosi, C., 2002, Les grands systèmes de droit contemporains, Paris, p. 283.

3 Whittaker, S., 2007, pp. 40-41.

4 Whittaker, S., 2007, p. 41. 
tion is whether the case that a judge has to try is identical to a previous one or not? If the two cases are identical the sitting judge in a subsequent case has to follow the authority of the previous one. If the cases are not identical the sitting judge will distinguish them.

The whole art of rendering judgments is on many occasions focused in distinguishing. It must be stressed that the distinguishing of cases needs ample reasoning. A judge is not allowed merely to state that the two cases are to be distinguished. He must supply convincing arguments for the preliminary decision to distinguish the cases. ${ }^{5}$

The main outcome of the distinguishing is to discard the binding force of a previous authority. If the case a judge has to try is different from the previous one the judge is not bound by the precedent.

\section{The Rule on Precedent in English LaW}

\subsection{EARLIER STAGE OF DEVELOPMENT}

Although the Common Law countries form one and the same family and the lawyers trained in Common Law use the same legal method, there are nevertheless slight differences in the approach to the binding force of precedent from one country to the other. This paper will treat the role of precedent in English law.

The binding force of precedent is sometimes understood as a consequence of the doctrine of stare decisis. The origin of the doctrine remains unclear and remote in the past.

In the old times it was accepted in English law that judges were allowed not to repeat wrong decisions. Therefore if a judge found a previous decision to be wrong he was entitled to hold otherwise in an identical case. From that ancient stage the courts' practice in England developed a firm stance on the binding force of precedent. The rules derived from precedents were to be applied "for the sake of uniformity and consistency even if they were 'not as convenient and reasonable as we ourselves could have devised"' 6

The doctrine of stare decisis "was elevated into inflexible dogma" only in the early $19^{\text {th }}$ century. ${ }^{7}$ It was followed in the first half of the $20^{\text {th }}$ cen-

5 On judge's reasoning the words of an Argentinian author are worth repeating. "It is necessary", he says, "to reason factually and legally". And further on he adds that the reasoning must be "refined". Cf. Gordillo, A., 2003, An Introduction to Law, London, p. 43.

6 Baker, J. H., 1979, An Introduction to English Legal History, London; the text between internal quotation marks is the expression of a judge given in the case of Mirehouse $v$. Rennell (1833).

7 Baker, J. H., 1979, eodem loco. 
tury, when the highest court in England (the House of Lords at that time) "was absolutely bound by the doctrine of stare decisis".

However, the rigidity that marked the doctrine on the binding force of precedent led to the question whether the highest court in England was bound by its own previous judgments. It was in 1966 that the question was entrenched.

\subsection{PRACTICE STATEMENT OF THE HOUSE OF LORDS}

The way of settling the important issue of the binding force of precedent on the judgments of the highest court in England was somewhat peculiar. It was done in a Practice Statement of the House of Lords in 1966.

The text of the statement was the following:

"Their Lordships nevertheless recognise that too rigid adherence
to precedent may lead to injustice in a particular case and also
unduly restrict the proper development of the law. They propose,
therefore, to modify their present practice and, while treating
former decisions of this House as normally binding, to depart
from a previous decision when it appears right to do so."

The stance expressed in the Practice Note has been maintained ever since. Their Lordships have not changed their attitude towards the binding force of precedent. In brief, the principle position is that precedents are to be adhered to, because they are binding, but the judges are nevertheless allowed to depart from them for the sake of justice in a particular case.

\section{Precedent in the JuRisprudence of the European Court of Human Rights}

\subsection{FOLLOWING OR OVERRULING A PREVIOUS JUDGMENT - THE BINDING FORCE OF PRECEDENT}

The European Court of Human Rights had to face the same issue as the English courts of law once upon a time. ${ }^{10}$ There was no written rule on the force of precedent. No legal text either in the European Convention on Human Rights or in its additional protocols could provide guidance to judges whether they should be bound by their own previous

8 Lord Denning, 1979, The Discipline of Law, London, p. 287. The author of the book sat as a justice of the House of Lords between 1957 and 1962.

9 Lord Denning, 1979, pp. 296-7. Cf. Baker, J. H., 1979, p. 175.

10 The European Court of Human Rights will hereinafter be referred to as the Court. 
rulings. ${ }^{11}$ Therefore, the developments, which took place in the Court's jurisprudence, were processes that may be labelled as the natural evolution of law.

The issue of the binding force of precedent clearly appeared before Strasbourg judges in the cases in which they had to decide whether to overrule a previous judgment. The whole set of ideas of binding force of precedent, following a precedent or distinguishing cases from previous ones was displayed before the Court. The Court's judgments given in several outstanding cases can furnish examples of the attitudes of judges towards precedents and the developments of the case law.

\subsubsection{THE CASE OF COSSEY - FOLLOWING REES}

In the case of Rees $v$. United Kingdom the applicant who was a transsexual complained under articles 8 and 12 of the Convention. ${ }^{12}$ The applicant stated that the domestic law did not "confer on him a legal status corresponding to his actual condition". ${ }^{13}$ His birth certificate mentioned only his sex at the time of birth and besides he could not marry a woman. ${ }^{14}$

The Court found no violation of the Convention provisions in this case. As to the Article 8 complaint the Court held that there was no positive obligation, which would extend so far as to include the duty of a member-state to make an entry into the public register after a gender assignment. ${ }^{15}$ As regards Article 12 complaint the Court held that under that provision the opposite biological sex of the partners was required to lawfully conclude a marriage. ${ }^{16}$

The same issues reappeared in Cossey v. United Kingdom. ${ }^{17}$ The applicant was a male to female transsexual. Her complaints were the same as those in the Rees case. She complained under Article 8 of the Convention about the non-recognition of her status, as regards the birth certificate. She also complained under Article 12 she was unable to marry. ${ }^{18}$ Notably, as far as the latter complaint is concerned, the applicant celebrated a marriage ceremony in a synagogue, but her marriage was subse-

11 The European Convention on Human Rights will hereinafter be referred to as the Convention.

12 ECtHR, Rees v. United Kingdom, no. 9532/81 (1986).

13 Paragraph 30 of the judgment.

14 Paragraphs 40 and 48.

15 Paragraph 44.

16 Paragraph 49.

17 ECtHR, Cossey v. United Kingdom, no. 10843/84 (1990).

18 Paragraph 27 of the judgment. 
quently pronounced void on the grounds that the two partners were not male and female. ${ }^{19}$

The Court posed two essential questions as foundations of its reasoning in the judgment. The first was: Is the present case distinguishable on its facts from the Rees case? And the second: Should the Court depart from its Rees judgment?

As to the first question it was observed that the applicant in Cossey indeed had a partner and even celebrated a ceremony, which had not been the case in Rees. However, the Court held the difference to be irrelevant and found the case at hand "not materially distinguishable" from the Rees case. ${ }^{20}$

To respond to the second question mentioned above the Court posed a rule to which we shall return further on in this text. Its essential element consists in the Court's stance that it should depart from a previous ruling only if "there were cogent reasons for doing so". ${ }^{21}$ The majority of judges held that the Court should not depart from the Court's previous ruling in Rees.

The majority reasoning in Cossey reproduced the Court's conclusions in Rees. There was no positive obligation of the respondent state to alter its system of the registration of births; therefore no violation of Article 8 of the Convention. ${ }^{22}$ As regards Article 12 complaint a reference was made to the paragraphs 49 and 50 of the Rees judgment; opposite biological sex was required for concluding marriage and there was no violation of the Convention. ${ }^{23}$

One of the dissenters in this case was judge Martens. His stance was that the case of Rees should have been decided differently, both under Articles 8 and $12 .{ }^{24}$

Besides, the dissenting judge held that there were cogent reasons for departing from the ruling in Rees. In his opinion "the Rees judgment was wrong", or at least "the present day conditions warranted a different decision". In general, the most important circumstance he relied on was the "ever-growing awareness of the essential importance of everyone's identi$t y$ ". ${ }^{25}$ The dissenting judge expressed the view that the judgment in Cossey should have overruled Rees.

19 Paragraph 14.

20 Paragraph 34.

21 Paragraph 35.

22 Paragraphs 38 and 40.

23 Paragraphs 43 and 48.

24 ECtHR, Cossey v. United Kingdom, no. 10843/84 (1990), judge Martens dissenting, items 3 and 4 .

25 Judge Martens dissenting, items 1.1 and 5.5. 
The judgment in Cossey thus followed the previous ruling in Rees, mostly on the grounds that the distinguishing was discarded. The judges in Strasbourg felt bound by the previous ruling in an identical case. That is evident from the wording of the judgment. The binding force of precedent was clearly confirmed, which was also evident from the dissent. The latter was in the line with the doctrine of precedent, because the dissenter had tried to find the way to overruling a precedent, which was regularly binding.

\subsubsection{THE AFTERMATH TO REES AND COSSEY - CHRISTINE GOODWIN CASE}

The case law concerning gender assignment had a turning point more than a decade after the judgment in Cossey was given. The leading case was Christine Goodwin v. United Kingdom. ${ }^{26}$ The applicant had a gender assignment; she was a postoperative male to female, complaining under both Articles 8 and 12 of the Convention.

The Court abandoned its previous stance and ruled for the applicant, finding violations of both provisions. As to the Article 8 complaint the Court referred to the judgments in Rees and Cossey, and reproduced the rule posed in the latter judgment. The Court held that the matter of birth register could no more be considered to fall within the margin of appreciation of the respondent state. ${ }^{27}$

The Court did the same in respect of Article 12 complaint. The rulings in Rees and Cossey were invoked and the Court held that the gender re-assignment in general did not fall within the margin of appreciation of a member-state to the Convention any more. The Court reasoned that there was "no justification for barring the transsexual from enjoying the right to marry under any circumstances". 28

In Christine Goodwin the Court applied a technique, which is specific for its own practice and jurisprudence. It altered the attitude towards the scope of the margin of appreciation in a class of cases. In substance however, the Court overruled its previous judgments given in the two cases that have been subject to attention in this paper.

\subsubsection{THE BORGERS CASE - OVERRULING DELCOURT}

Historically speaking the overruling of the Court's previous stance, which occurred in Christine Goodwin was a consequence of the social

26 ECtHR, Christine Goodwin v. United Kingdom, no. 28957/95 (2002).

27 Paragraphs 73, 74 and 93 of the judgment.

28 Paragraph 103 for the quotation and 96 for the reference to the previous cases. 
evolution in Europe. The attitude of the public at large towards an issue had been changed before the Court joined it and its decision only mirrored the social developments.

If we were to trace our topic, i.e. the binding force of precedent in the Court's case law, we should return to the last decades of the $20^{\text {th }}$ century. A pair of cases against Belgium can display the Court's attitude towards the problem. ${ }^{29}$

The first of the two cases was Delcourt v. Belgium. ${ }^{30}$ The applicant was a person that had been charged with criminal offences, tried and convicted to prison in Belgium. His complaint under Article 6 of the Convention was based on the fact that the state official in charge of prosecution participated in the deliberations of the Cassation Court. That was prescribed by the Belgian procedural law, which relied on traditions of the country and was more than 150 years old. The applicant claimed lack of impartiality of the Cassation Court and alleged there was a violation of Article 6 of the Convention. The Court found Article 6 applicable to the case, but ruled that there had been no violation of that provision. ${ }^{31}$

The Court revisited the issue in Borgers v. Belgium. ${ }^{32}$ The applicant in that case was a lawyer charged with forgery and using forged documents. ${ }^{33}$ His complaint under Article 6 of the Convention was the same as the one the Court had to deal with in Delcourt.

The sitting judges of the Court were fully aware of the binding force of precedent. It is most likely that such an awareness made them put a special paragraph in the reasoning of the judgment. Its purpose was to determine the Court's stance towards a previous ruling that appeared to be the leading case.

The Court stated that "findings in the Delcourt judgment on the question of the independence and impartiality of the Court of Cassation and its procureur general's department remain entirely valid". ${ }^{34}$ That was indeed the crucial matter in the precedent, which the judges considered binding. However, the Court ruled differently from the previous case and found a

29 For more information see: Popović, D., "The Role of Precedent in the Jurisprudence of the European Court of Human Rights", in: The European Convention on Human Rights, a living instrument - Essays in Honour of Christos L. Rozakis, 2011, Brussels, pp. 467-483.

30 ECtHR, Delcourt v. Belgium, no. 2689/65 (1970).

31 Paragraphs 26 and 37 of the judgment.

32 ECtHR, Borgers v. Belgium, no. 12005/86 (1991).

33 Paragraph 11 of the judgment.

34 Paragraph 24. 
violation of Article 6 of the Convention. To find reasons for such a verdict the Court relied on the rights of defence, the principle of the equality of arms and the role of appearances. ${ }^{35}$

The Court concluded that the state official present at the deliberations of the Cassation Court could not be considered neutral. Further on, the applicant could not reply to his submissions and eventually the deliberations in the presence of the state official could give the latter an opportunity to promote his submissions, without contradiction from the applicant. $^{36}$

The judges were not unanimous to reach the verdict in Borgers. Some of the arguments of the dissenters can display the sentiments they had concerning the binding force of precedent.

Judge Cremona expressed the view that the previous judgment in Delcourt was overruled. He was against the overruling and preferred to stick to the previous stance. ${ }^{37}$

Judge Thor Vilhjalmsson declared himself bound by the previous precedent, from which he was not ready to depart. ${ }^{38}$ Judges Pinheiro Farinha and Morenilla disagreed with the majority statement that the findings in Delcourt were still valid. They agreed with the operative provisions of the judgment in Borgers, but on the other hand rejected the majority statement in the first sentence of paragraph 24 of the judgment. ${ }^{39}$

Judge Martens invoked the ruling in Cossey. He was a dissenter in Cossey on the grounds that he had found cogent reasons to depart from the previous ruling in Rees. There were no such reasons in the case at hand, so he was against the overruling. The dissenting judge declared he shared the "analysis and the assessment" of the previous judgment and saw no reasons for overruling. He felt bound by the precedent. ${ }^{40}$

The judgment in Borgers overruled a precedent. Nevertheless, the whole set of arguments presented by the majority and the dissenters clearly shows that precedent had a binding force for the Court, as early as at the beginning of 1990s.

35 Paragraph 29.

36 Paragraphs 26-28.

37 ECtHR, Borgers v. Belgium, no. 12005/86 (1991), judge Cremona dissenting.

38 ECtHR, Borgers v. Belgium, no. 12005/86 (1991), judge Thor Vilhjalmsson dissenting.

39 ECtHR, Borgers v. Belgium, no. 12005/86 (1991), judges Pinheiro Farinha and Morenilla dissenting, items 1 and 2 .

40 ECtHR, Borgers v Belgium, no. 12005/86 (1991), judge Martens dissenting, items 2.5 and 3.10. 


\subsubsection{THE CASE OF HUBER - OVERRULING SCHIESSER}

In two cases against Switzerland the problem was the same. It concerned the binding force of precedent and the question was whether the Court should stick to its previous ruling or not?

In the case of Schiesser $v$. Switzerland the applicant was a person who had been detained following an order of a District Attorney. ${ }^{41}$ The latter is indeed an organ of prosecution. Therefore the applicant filed a complaint under Article 5 of the Convention. The Court found no violation in the case, stating that the District Attorney in Swiss law offered sufficient guarantees of independence. In the Court's view he could qualify as "officer authorised by law to exercise judicial power", as provided in Article 5.3 of the Convention. ${ }^{42}$

In Huber v. Switzerland it was again a District Attorney who had signed a detention order to detain the applicant. ${ }^{43}$ Ms Huber alleged a violation of Article 5.3 of the Convention. ${ }^{44}$

The Court's reasoning in this case was peculiar, which makes it ambiguous whether Huber should be considered as following or overruling previous jurisprudence. In any case it supplies evidence on the binding force of precedent. Namely, there was a clear precedent in Schiesser speaking against finding a violation of Article 5.3 of the Convention. District Attorney under Swiss law could qualify as an officer authorised by law to exercise judicial power.

The Court nevertheless referred to its rulings in three judgments rendered against the Netherlands, posterior to the Court's ruling in Schiesser. They were all about detention of military personnel following orders of the officer called auditeur-militar in Dutch law. That officer had a prosecuting role and could not be independent of the parties. That is what made the Court rule in favour of the applicants in all cases mentioned. ${ }^{45}$

The Court overruled its stance in Schiesser on the grounds of reference to the Dutch precedents. The District Attorney in Swiss law also had a prosecution role, and the Court found his impartiality "open to doubt". ${ }^{46}$

41 ECtHR, Schiesser v. Switzerland, no. $7710 / 76$ (1979), paragraph 7.

42 Paragraph 38 of the judgment.

43 ECtHR, Huber v. Switzerland, no. 12794/87 (1990), paragraph 12.

44 Paragraph 37 of the judgment.

45 Paragraph 42 of the judgment; see the explanation as well as the references to the Court's judgments in the Dutch cases.

46 Paragraph 43. 


\title{
3.2. THE WORDING OF THE RULE ON THE BINDING FORCE OF PRECEDENT
}

The Court's stance on the binding force of precedent appeared in clear-cut wording in Cossey. The Court stated as follows:

\begin{abstract}
"The Court is not bound by its previous judgments. However, it usually follows and applies its own precedents, such a course being in the interests of legal certainty and the orderly development of the Convention case law. Nevertheless, this would not prevent the Court from departing from an earlier decision if it was persuaded that there were cogent reasons for doing so." 47
\end{abstract}

The formula was used in judgments given after 1990. It was subject to slight modifications in some judgments, but its substance was completely preserved. Thus in Beard v. United Kingdom and in Chapman v. United Kingdom the text was slightly altered. It read:

"The Court considers that while it is not formally bound to follow any of its previous judgments, it is in the interests of legal certainty, foreseeability and equality before the law that it should not depart, without good reason, from precedents laid down in previous cases." 48

In both judgments the Court referred to the paragraph 35 in Cossey, which spelt out the formula for the first time. The cases of Beard and Chapman concerned Roma population in England on caravan sites. The Court found no violation in either of the two and followed its previous jurisprudence in Buckley, a case given judgment in $1996 .{ }^{49}$

The wordings used in Cossey on one hand and in Beard and in Chapman on the other are very much alike. The principal stance is the same in both texts. The precedents are not binding for the Court, but it nevertheless follows them. The reasons for such a practice were not put in the same wording in the two formulas mentioned.

In Cossey the reasons for following precedents were the legal certainty and the orderly development of the Convention case law. In Beard and in Chapman the reasons were legal certainty, foreseeability and equality before the law.

47 ECtHR, Cossey v. United Kingdom, no. 10843/84 (1990), paragraph 35.

48 ECtHR, Beard v. United Kingdom, no. 24882/94 (2001) paragraph 81; ECtHR, Chapman v. United Kingdom, no. 27238/95 (2001) paragraph 70. The Court gave judgments in both cases on the same day - 18 January 2001.

49 ECtHR, Buckley v. United Kingdom, no. 20348/92 (1996); cf. paragraph 103 in Beard and paragraph 96 in Chapman, where the ruling in Buckley was followed. 
In the closing parts of the statements there is also a slight difference, although they are basically the same. The Court is allowed to depart from a previous precedent. The entitlement to depart is laid down on "cogent reasons" in Cossey and on "good reason" in Beard and in Chapman.

In Christine Goodwin the formula was reproduced. The text of the judgment referred to Chapman, where the text was taken from without alterations. ${ }^{50}$

The Court used the same formula on the binding force of precedent in its judgment in the Stafford case. ${ }^{51}$ The formula in Stafford was the combination of those in Cossey and in Chapman in the sense that it stated "legal certainty, foreseeability and equality before the law" as reasons for following precedents and "cogent reason" for departing. The former expression was from Chapman; the latter was from Cossey, but it was put in plural, instead of the singular in the original.

In the judgment of the case of Mamatkulov and Askarov v. Turkey the Court made reference to both Chapman and Christine Goodwin and returned to the wording in the former judgment for the most part. The reasons for following precedents were legal certainty and foreseeability. The equality before the law was omitted in the formula. Departing from a precedent could not apply "without good reason". ${ }^{2}$

Although there were slight alterations in the wording of the rule on precedent in the Court's jurisprudence the formula stemming from the judgment in Cossey was substantially maintained. It says: (a) that the Court is not formally bound by its own previous rulings; (b) that the Court follows the precedents for the sake of some important interests, among which legal certainty; (c) that the Court is allowed to depart from its previous judgments if good/cogent reasons so advise.

\section{Conclusions}

The Court's stance on the binding force of precedent, as distilled here, should be compared to the Practice Statement of the Law Lords of England. Their starting points are different. The Law Lords wanted to avoid too rigid adherence to precedent. The Court on the other hand declared that precedents were not formally binding. However, the Court also stated it would adhere to precedents for the sake of legal certainty and some

50 ECtHR, Christine Goodwin v. United Kingdom, no. 28957/95 (2002), paragraph 74.

51 ECtHR, Stafford v. United Kingdom, no. 46295/99 (2002), paragraph 68.

52 ECtHR, Mamatkulov and Askarov v. Turkey, no. 46827/99, 46951/99 (2005), paragraph 121. 
other interests. That is what led to the substantial equality of the positions of the English and the European judges on the issue. They both follow precedents. Their practices indeed rely on the "overarching principles and values of law" ${ }^{53}$

Both English and European jurisdictions agree that it may be justified to depart from precedent in a certain case. The grounds for this are however not the same for both. When doing so, the English will stick to justice and the Europeans to a good or cogent reason.

Having examined the positions of the two jurisdictions it is essential to underline that following precedents appears to be indispensable, no matter what arguments may serve as grounds for such a practice.

It has been remarked among academics that "there is no profound difference between the working of Common Law and contemporary European continental law: all tribunals employ the same method of approach to a case law" ${ }^{54}$ Were the judges to perform their task otherwise, justice would not be properly served.

\section{BIBLIOGRAPHY}

1. Baker, J. H., 1979, An Introduction to English Legal History, London.

2. David, R., Jauffret-Spinosi, C., 2002, Les grands systèmes de droit contemporains, Paris.

3. Lord Denning, 1979, The Discipline of Law, London.

4. Gordillo, A., 2003, An Introduction to Law, London.

5. Popović, D., "The Role of Precedent in the Jurisprudence of the European Court of Human Rights", in: 2011, The European Convention on Human Rights, a living instrument - Essays in Honour of Christos L. Rozakis, Brussels.

6. Whittaker, S., "Precedent in English Law: A view from the citadel", in: Hondius, E. (ed.), 2007, Precedent and the Law, Brussels.

\section{Case Law}

1. ECtHR, Beard v. United Kingdom, no. 24882/94 (2001).

2. ECtHR, Borgers v. Belgium, no. 12005/86 (1991).

3. ECtHR, Buckley v. United Kingdom, no. 20348/92 (1996).

4. ECtHR, Chapman v. United Kingdom, no. 27238/95 (2001).

5. ECtHR, Christine Goodwin v. United Kingdom, no. 28957/95 (2002).

53 Gordillo, A., 2003, 137.

54 Gordillo, A., 2003, pp. 137-138. 
6. ECtHR, Cossey v. United Kingdom, no. 10843/84 (1990).

7. ECtHR, Delcourt v. Belgium, no. 2689/65 (1970).

8. ECtHR, Huber v. Switzerland, no. 12794/87 (1990).

9. ECtHR, Mamatkulov and Askarov v. Turkey, no. 46827/99, 46951/99 (2005).

10. ECtHR, Rees v. United Kingdom, no. 9532/81 (1986).

11. ECtHR, Schiesser v. Switzerland, no. 7710/76 (1979).

12. ECtHR, Stafford v. United Kingdom, no. $46295 / 99$ (2002).

\title{
ŠTA SU PRECEDENTI I KAKAV BI STAV TREBALO \\ DA IMAJU SUDIJE PREMA PRECEDENTIMA? ODGOVORI KOJE NUDI JURISPRUDENCIJA EVROPSKOG SUDA ZA LJUDSKA PRAVA
}

\author{
Dragoljub Popović
}

\section{REZIME}

Pravnik obrazovan u duhu evropskog kontinentalnog prava često je sklon da tvrdi kako u njegovoj zemlji presedan ne obavezuje sud. Kao razlog za to lakonski se navodi činjenica da ta zemlja ne pripada pravnome krugu anglosaksonskog prava. Ovakvo tvrđenje treba, međutim, razjasniti. Autor članka postavlja pitanje da li to znači da sudija može jednog dana presuditi u korist tužioca, a sledećeg $\mathrm{u}$ istovetnoj vrsti spora u korist tuženoga? Odgovor na ovo pitanje mora biti odrečan, što pokazuje da je pitanje o vezanosti suda ranijom presudom kompleksnije nego što izgleda na prvi pogled i upravo nadilazi pravne porodice. Ono je univerzalnog karaktera i u vezi je sa samim pojmom pravde.

U anglosaksonskom pravu se smatra da svaka presuda ima odlučujući sastojak, ono što je sudiju navelo da presudi onako kako je presudio. Taj sastojak se zove ratio decidendi i u suštini samo taj element presude obavezuje sudiju. Zato se sudija, kad presuđuje spor, pita da li je predmet koji treba da presudi istovetan s prethodnim, koji se ukazuje kao presedan. Ako jeste, sudija se povodi za presedanom. Ako nađe da dva slučaja nisu istovetna, mora to valjano obrazložiti i pribeći onome što se zove razlikovanje slučajeva.

U engleskom pravu je pravilo o primeni presedana fiksirala jedna načelna izjava najvišeg suda od 1966. godine, koja je postavila pravilo. To pravilo kaže da je engleski najviši sud vezan sopstvenom ranijom odlukom, ali da uprkos tome od ove može odstupiti kad za to nađe opravdane razloge. Valja primetiti kako je ovaj stav samo uobličio shvatanje o ulozi presedana koje se u praksi polako stvaralo tokom vekova. 
Evropski sud za ljudska prava nije imao nikakvo uporište za primenu doktrine presedana u tekstu Evropske konvencije za zaštitu ljudskih prava i osnovnih sloboda, ali je u praksi razvio shvatanje koje uvažava ulogu presedana. U jednom nizu presuda, koje su u članku podvrgnute raščlanjavanju, Evropski sud je donosio svoje izreke povodeći se za ranijim presudama. To je dovelo do formulisanja jedne vrste pravila koje se ponavlja u praksi Evropskog suda i svedoči o odnosu njegove jurisprudencije prema presedanu. Evropski sud polazi od sasvim suprotnog stava u odnosu na onaj kojim se rukovodio najviši sud u Engleskoj. Po shvatanju evropskih sudija, presedan načelno ne obavezuje, ali se uprkos tome obavezno primenjuje iz razloga pravne sigurnosti i jednakosti pred zakonom.

Poređenje dvaju pristupa problemu presedana pokazuje konvergenciju shvatanja engleskih i evropskih sudija. Dok oni prvi smatraju da presedan obavezuje, ali se od njega ipak može odstupiti kad to zahteva pravičnost, ovi drugi su mišljenja da presedan načelno ne obavezuje, ali ga se ipak moramo pridržavati iz razloga pravne sigurnosti i jednakosti pred zakonom.

Ključne reči: precedent, razlikovanje, odstupanje, obavezujuća primena, sprovođenje pravde.

Dostavljeno Redakciji: 8. aprila 2017. god.

Prihvaćeno za objavljivanje: 20. juna 2017. god. 